\title{
Analysis of Vitamin D Receptor Gene Polymorphism in Chronic Periodontitis among Saudi Population
}

\author{
Fathy M. Elfasakhany ${ }^{1,2}$ Omaima N. Al-Qahtani \\ ${ }^{1}$ Department of Basic and Clinical Oral Sciences, Faculty of \\ Dentistry, Umm Al Qura University, Makkah, Saudi Arabia \\ ${ }^{2}$ Department of Medical Biochemistry, Faculty of Medicine, Tanta \\ University, Tanta, Egypt \\ ${ }^{3}$ Dental Intern Program, Faculty of Dentistry, Umm Al Qura \\ University, Makkah, Saudi Arabia \\ ${ }^{4}$ Department of Periodontology and implant Dentistry, Faculty of \\ Dentistry, Ain Shams University, Egypt
}

\author{
Asmaa M. Badri ${ }^{3}$ Hala A. Abuelela ${ }^{4}$
}

Eur Dent Res Biomater J 2021;2:12-16.

\author{
Address for correspondence Fathy M. Elfasakhany, Department of \\ Basic and Clinical Oral Sciences, Faculty of Dentistry, Umm Al Qura \\ University, Makkah, Abdia 715, Saudi Arabia \\ (e-mail: fmfasakhany@uqu.edu.sa).
}

\begin{abstract}
Keywords

- Apal

- Taql

- gene polymorphism

- periodontitis

- vitamin D receptor

- polymerase chain reaction

Objective Genetic and environmental factors have important roles in the development of periodontitis. We aimed to assess the relation of vitamin $\mathrm{D}$ receptor (VDR) Apal and Taql polymorphisms and the susceptibility of periodontitis in Saudi population in Makkah region.

Materials and Methods In total, 86 unrelated patients with moderate-to-severe periodontitis and 86 controls were enrolled in this study. Evaluation of the periodontal state was performed by using plaque index, bleeding on probing, probing depth, and attachment loss. Extraction of genomic DNA from peripheral blood and genotyping of VDR gene Apal G/T (rs7975232) and TaqI T/C (rs731236) polymorphisms were performed by utilizing polymerase chain reaction and restriction digestion.

Results There were statistically significant differences between both groups regarding the mean bleeding on probing, mean probing depth, mean plaque index, and the mean attachment level $(p<0.001)$ indicating that the matching based on the investigated groups was adequate. The examined populations were in Hardy-Weinberg equilibrium. Analysis of the genotype and allele frequencies of both VDR Apal and Taql single nucleotide polymorphisms revealed that they were statistically indifferent between the control group and the periodontitis subjects ( $p>0.05)$.

Conclusion These results suggested that VDR Apal and Taql polymorphisms might not be related to the susceptibility of periodontal disease in the Saudi subjects in Makkah region.
\end{abstract}

\section{Introduction}

Periodontal disease is a chronic infectious condition of the teeth surrounding tissues and is often reported as a multifactorial ailment with gradual progression. The phenotype of this condition is determined by both hereditary and environmental elements. ${ }^{1-4}$ The most remarkable etiologic and scientific criteria of the condition are the formation of microbial plaque, inflammation of the periodontium, and damage of the supporting ligament and alveolar bone. ${ }^{5}$ The rate of occurrence and progression of the condition increase with the age and generally affects each gender
DOI https://doi.org/ 10.1055/s-0041-1727090 (c) 2021. European Dental Research and Biomaterials Journal.

This is an open access article published by Thieme under the terms of the Creative Commons Attribution-NonDerivative-NonCommercial-License, permitting copying and reproduction so long as the original work is given appropriate credit. Contents may not be used for commercial purposes, or adapted, remixed, transformed or built upon. (https://creativecommons.org/licenses/by-nc-nd/4.0/).

Thieme Medical and Scientific Publishers Pvt. Ltd. A-12, 2nd Floor, Sector 2, Noida-201301 UP, India 
equally. Additionally, periodontal disease is frequently seen among families, indicating a genetic predisposition to the condition. ${ }^{6,7}$ Moreover, numerous studies reported the role of several gene polymorphisms in periodontitis as the gene polymorphism may lead to change in the structure or expression of the gene product, and this may alter the innate and adaptive immunity which will determine the disease outcome. ${ }^{8}$ As long as the resorption of the alveolar bone is a prominent feature of periodontitis, it is reasonable that regulators of bone metabolism such as vitamin D and its nuclear receptor (vitamin $\mathrm{D}$ receptor [VDR]) gene polymorphisms may be related to the periodontitis. Along with their role in bone homeostasis, vitamin D and its receptor affect the monocyte phagocytic function and differentiation. ${ }^{9}$

Vitamin D performs its action by interaction with its nuclear receptor (VDR) and form a complex with the gene response element to regulate different biological processes. ${ }^{10}$ VDR is a member of a family of transcriptional factors and has a sequence similarity to the receptors of thyroid and steroid hormones. ${ }^{11}$

VDR gene that encodes VDR has nine exons that span approximately $100 \mathrm{~kb}$ long located in chromosome 12q13.11, and it is expressed in thyroid gland, kidney, bone, intestine, and other tissues. ${ }^{12}$

Several single nucleotide polymorphisms were identified in the VDR genes like TaqI, BsmI, ApaI, and FokI, and several studies have examined the relation between these VDR polymorphisms and the susceptibility to periodontitis in different ethnic populations. ${ }^{13,14}$

Hence, the results of studies on VDR gene polymorphism in periodontitis in various ethnicities showed contrary results; we assessed the relation between the VDR genes ApaI and TaqI polymorphisms and periodontitis in Saudi subjects. To our information from literature, this is the first report about the association of VDR gene ApaI G/T and TaqI T/C polymorphisms and periodontal disease in Saudi subjects in Makkah region.

\section{Materials and Methods}

\section{Study Design and Participants}

A total of 172 subjects ( 86 unrelated patients having moderate-to-severe periodontitis and 86 controls) were enrolled in this cross-sectional study. All participants were Saudi subjects who were chosen from the dental clinic, school of dentistry, Umm AL Qura University, Saudi Arabia. The controls included in the study were free from both periodontal and systemic ailments. Both study groups were matched concerning the age (30-50 years) and gender, and both should have at least 20 teeth. The exclusion criteria were systemic ailments, lactation, pregnancy, preceding orthodontic treatments, immunodeficiency diseases, chemotherapy, and smokers. The size of the sample was considered depending on a preceding study and was increased by approximately $35 \%$ to preserve the evaluation at an optimal degree of precision (5\%) against the possibility of the sample size reduction due to disavowal and withdrawals. ${ }^{15}$ This study got approval from the ethical committee of the School of Dental sciences, Um Al qura University, Kingdom of Saudi. All participating individuals have filled and signed informed consent prior to enrolment in the study.

\section{Clinical Evaluation}

The periodontal status of all subjects was evaluated by two trained and calibrated investigators using plaque index (PI), pocket depth (PD), clinical attachment loss (CAL) and bleeding on probing (BOP) utilizing Williams periodontal probe. ${ }^{16-18}$ Patients with $\mathrm{PD} \geq 5 \mathrm{~mm}$, BOP, CAL $\geq 3 \mathrm{~mm}$, and bone loss $\geq 20 \%$ on radiographic examination were enrolled in the study. The updated statement of the American Academy of Periodontology was used for characterization of the periodontal disease. ${ }^{19}$

\section{DNA Extraction}

Peripheral blood was withdrawn from all individuals in tri-potassium ethylene diamine tetraacetate-coated vacutainer and was utilized for DNA extraction by using commercial kit (Blood Mini Kits, Qiagen, Germany). The purified DNA was used in the polymerase chain reaction (PCR) experiment.

\section{Vitamin D Receptor Apal and Taql Genotyping}

A single PCR amplification was performed by using primers that span the ApaI and TaqI polymorphic sites as described before with slight modifications. ${ }^{20}$ The primers used were: 5'-CAGAGCATGGACAGGGAGCAAG-3' as forward primer and 5'-GCAACTCCTCATGGCT GAGGTCTCA-3' as reverse primer. After an initial step of $94^{\circ} \mathrm{C}$ for 5 minutes, 30 cycles of $94^{\circ} \mathrm{C}$ for 1 minute, $68^{\circ} \mathrm{C}$ for 1 minute, $72^{\circ} \mathrm{C}$ for 1 minute, and a final step at $72^{\circ} \mathrm{C}$ for 7 minutes. The PCR fragment (740 bp) was treated with TaqI and ApaI restriction enzymes. Fragments were electrophoretically separated on $2 \%$ agarose. Digestion with Apal gave single band of 740 bp for the TT genotype and two bands of 530 and 210 bp for the GG genotype. TaqI digestion gave two bands of 495 and 245 bp with the TT genotype (due to presence of an obligatory polymorphic site) and three bands of 205, 245, and 290 bp with the CC genotype. The genotypes after restriction digestion are shown in - Fig. 1 .

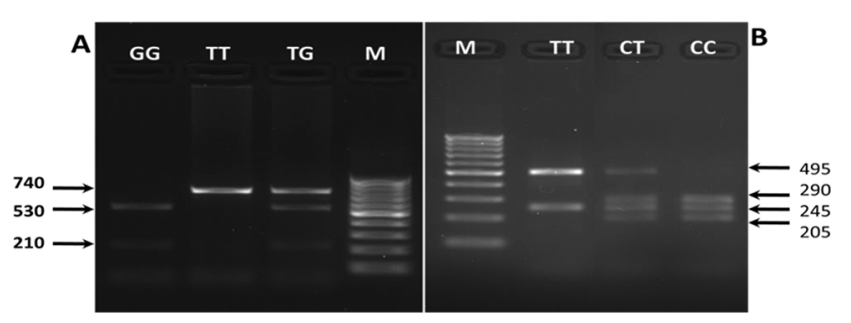

Fig. 1 Agarose electrophoresis of VDR Apal and Taql genotypes. The 740-bp polymerase chain reaction products of the VDR gene were digested with Apal (A) and Taql (B) restriction enzymes before their resolving in an agarose gel and visualized by UV light. Lane M $=$ DNA molecular ladders (100-1,000 bp). The remaining lanes correspond to the genotypes labeled at the top of each photo. VDR, vitamin $\mathrm{D}$ receptor. 


\section{Statistics}

SPSS version 21 was used for data analysis. Continuous variables were analyzed by utilizing Student's $t$-test, while the categorical data were analyzed by using Chi-square test. A $p$-value $<0.05$ was considered significant.

\section{Results}

\section{Clinical Analysis}

The demographic and clinical data are shown in - Table 1. The mean values of PI, CAL, BOP, and PD were higher in the periodontitis group compared with the controls $(p<0.001)$. This confirmed that the two groups were matched adequately.

\section{Taql Polymorphism}

- Table 2 showed the distribution of genotypes and alleles of TaqI polymorphism which was in Hardy-Weinberg equilibrium (HWE) in both groups. In the controls, the TT, TC, and CC genotypes were $41.86,41.86$, and $16.28 \%$, and they were $38.37,43.02$, and $18.61 \%$ in the patients' group, respectively. The ratio of $\mathrm{T}$ allele was 62.79 and $59.88 \%$, while C allele was 37.21 and $40.12 \%$ in controls and the periodontitis subjects, respectively. The TaqI genotype and allele frequencies were indifferent between both groups $(p>0.05)$.

\section{Apal Polymorphism}

The genotype and allele distributions of Apal G/T polymorphism of both study groups are presented in $\mathbf{- T a b l e ~} 2$.
Table 1 Demographic and clinical data of study subjects

\begin{tabular}{|l|l|l|l|}
\hline Characteristic & $\begin{array}{l}\text { Control } \\
\text { group } \\
(86)\end{array}$ & $\begin{array}{l}\text { Periodontitis } \\
\text { group } \\
(86)\end{array}$ & $p$-Value \\
\hline Age (y) & $41.84 \pm 5.86$ & $42.22 \pm 5.96$ & 0.671 \\
\hline Gender (M/F) & $51 / 35$ & $47 / 39$ & 0.538 \\
\hline BOP (\%) & $8.53 \pm 1.1$ & $49.67 \pm 7.06$ & $<0.001$ \\
\hline PD (mm) & $1.17 \pm 0.5$ & $5.06 \pm 0.79$ & $<0.001$ \\
\hline CAL (mm) & $0.67 \pm 0.22$ & $4.85 \pm 0.88$ & $<0.001$ \\
\hline PI (\%) & $4.88 \pm 0.52$ & $48.71 \pm 3.66$ & $<0.001$ \\
\hline
\end{tabular}

Abbreviations: BOP, bleeding on probing; CAL, clinical attachment loss; $\mathrm{PD}$, pocket depth; PI, plaque index.

Note: Data are shown as mean \pm standard deviation.

The genotype distribution was in HWE in both groups. In the controls, the TT, TG, and GG genotypes were 47.67, 32.56, and $19.77 \%$, and they were $40.69,44.19$, and $15.12 \%$ in the periodontal disease, respectively. The percentage of the $\mathrm{T}$ allele was 61.63 and $62.79 \%$, while G allele was 38.37 and $37.21 \%$ in the controls and the periodontitis subjects, respectively. The ApaI genotype and allele frequencies were indifferent between the controls and the periodontitis subjects $(p>0.05)$.

Table 2 Vitamin D receptor Apal and Taql single nucleotide polymorphisms in the study group

\begin{tabular}{|c|c|c|c|c|c|c|c|}
\hline & \multicolumn{2}{|c|}{$\begin{array}{l}\text { Control } \\
(N=86)\end{array}$} & \multicolumn{2}{|c|}{$\begin{array}{l}\text { Periodontitis } \\
(N=86)\end{array}$} & \multirow[t]{2}{*}{$p$-Value } & \multirow[t]{2}{*}{ Odds ratio } & \multirow[t]{2}{*}{$95 \% \mathrm{Cl}$} \\
\hline & $N$ & $\%$ & $N$ & $\%$ & & & \\
\hline \multicolumn{8}{|c|}{ Taql polymorphism } \\
\hline \multicolumn{8}{|c|}{ Genotypes } \\
\hline TT & 36 & 41.86 & 33 & 38.37 & & 1 & \\
\hline CT & 36 & 41.86 & 37 & 43.02 & 0.74 & 1.121 & $0.58-2.166$ \\
\hline CC & 14 & 16.28 & 16 & 18.61 & 0.832 & 0.899 & $0.384-2.107$ \\
\hline \multicolumn{8}{|c|}{ Alleles } \\
\hline $\mathrm{T}$ & 108 & 62.79 & 103 & 59.88 & & 1 & \\
\hline C & 64 & 37.21 & 69 & 40.12 & 0.841 & 1.176 & $0.534-2.588$ \\
\hline \multicolumn{8}{|c|}{ Apal polymorphism } \\
\hline \multicolumn{8}{|c|}{ Genotypes } \\
\hline TT & 37 & 47.67 & 35 & 40.69 & & 1 & \\
\hline TG & 32 & 32.56 & 38 & 44.19 & 0.508 & 1.255 & $0.649-2.427$ \\
\hline GG & 17 & 19.77 & 13 & 15.12 & 0.385 & 1.553 & $0.656-3.676$ \\
\hline \multicolumn{8}{|c|}{ Alleles } \\
\hline $\mathrm{T}$ & 106 & 61.63 & 108 & 62.79 & & 1 & \\
\hline G & 66 & 38.37 & 64 & 37.21 & 0.547 & 0.723 & $0.327-1.598$ \\
\hline
\end{tabular}

Note: Chi-square analysis of genotypes between subjects with periodontitis and controls. 


\section{Discussion}

Periodontal disease is a chronic infection of the tissues surrounding the teeth that leads to destruction of the tooth supporting tissue and alveolar bone owing to the interaction between pathogenic bacteria and host immune response. ${ }^{1}$

The mode of host immune response to the etiologic bacteria depends on genetic factors of the host that may lead to or protect from the disease. Several candidate genes were investigated, but the results show controversy. Of these genes is the VDR gene that encodes the VDR that mediates the action of vitamin $\mathrm{D}$ in bone metabolism and immunomodulation. ${ }^{14}$ We investigated the relationship between VDR ApaI and TaqI polymorphisms and periodontal disease in a group of Saudi individuals in Makkah region of Saudi Arabia. We found no association between both Apal and TaqI polymorphisms and periodontitis; therefore, both VDR ApaI and TaqI polymorphisms may not carry a risk for periodontitis among Saudis. Similar results were obtained with other investigators in different ethnic populations (Turkish population, ${ }^{21}$ Han Chinese subjects, ${ }^{22}$ Colombian population, ${ }^{23}$ Iranian population, ${ }^{24}$ Taiwanese Han ethnic population, ${ }^{25}$ the Tamilian population, ${ }^{26}$ and the Western Romanian population ${ }^{27}$ ). However, contrary results were obtained with other investigators. VDR ApaI GG genotype was reported to be related to the risk of chronic periodontitis $(\mathrm{CP})$ in the Jordanian population, ${ }^{28}$ while ApaI T allele was found to be related to the susceptibility to $\mathrm{CP}$ in Han Chinese nationality, ${ }^{29}$ whereas VDR TaqI TT genotype was found to be related to $\mathrm{CP}$ in Japanese subjects, ${ }^{30}$ Italian population ${ }^{31}$ and in $\mathrm{CP}$ smokers in Caucasians, ${ }^{32}$ while the TaqI CC genotype was found to be related to $\mathrm{CP}$ in Chinese subjects. ${ }^{33}$ These contrary results may be interpreted by different ethnic background or exposure to different environmental conditions.

According to the above, it is obvious that the results of research on the relationship of VDR gene polymorphisms and the risk of periodontal disease differ between various ethnicities.

To our knowledge, this is the first report assessing the relation between VDR TaqI and ApaI polymorphisms and the risk of periodontal disease in Saudi Arabia.

VDR polymorphisms were studied in other systemic disorders other than periodontal disease such as osteoporosis, diabetes mellitus, cancer, coronary heart disease, and chronic renal failure. ${ }^{34-38}$ This study has some limitations, especially the sample size that was not large enough, and so further studies will be required to include a larger cohort of patients with different forms of periodontal disease with clinical data and serological analysis to clarify the role of vitamin D and VDR polymorphism in the progression of periodontitis.

\section{Conclusion}

The findings obtained in this study indicated that VDR ApaI G/T and TaqI T/C polymorphisms might not be related to the risk of periodontal disease in Saudi subjects in Makkah region.
Funding

None.

\section{Conflict of Interest}

None declared.

\section{Acknowledgment}

The authors appreciated the technical help of Dr. Abd Elrahman Sabry in the molecular laboratory in our school. They also thank Dr. Abd El Aziz Yasen for his support in the section of statistics.

\section{References}

1 Newman MG, Takei HH, Klokkevold PR, Carranza FA, Newman and Carranza's clinical periodontology. 13th ed. Philadelphia, Elsevier; 2019:342-351

2 Michalowicz BS, Aeppli D, Virag JG, et al. Periodontal findings in adult twins. J Periodontol 1991;62(5):293-299

3 Michalowicz BS, Diehl SR, Gunsolley JC, et al. Evidence of a substantial genetic basis for risk of adult periodontitis. J Periodontol 2000;71(11):1699-1707

4 Bayani M, Pourali M, Keivan M. Possible interaction between visfatin, periodontal infection, and other systemic diseases: a brief review of literature. Eur J Dent 2017;11(3):407-410

5 Ohlrich EJ, Cullinan MP, Seymour GJ. The immunopathogenesis of periodontal disease. Aust Dent J 2009;54(Suppl 1) :S2-S10

6 Könönen E, Gursoy M, Gursoy UK. Periodontitis: a multifaceted disease of tooth-supporting tissues. J Clin Med 2019;8(8):1135

7 Toy VE, Uslu MO. Do genetic polymorphisms affect susceptibility to periodontal disease? A literature review. Niger J Clin Pract 2019;22(4):445-453

8 Chapple IL, Bouchard P, Cagetti MG, et al. Interaction of lifestyle, behaviour or systemic diseases with dental caries and periodontal diseases: consensus report of group 2 of the joint EFP/ORCA workshop on the boundaries between caries and periodontal diseases. J Clin Periodontol 2017;44(Suppl 18) :S39-S51

9 Selvaraj P, Chandra G, Jawahar MS, Rani MV, Rajeshwari DN, Narayanan PR. Regulatory role of vitamin D receptor gene variants of Bsm I, Apa I, Taq I, and Fok I polymorphisms on macrophage phagocytosis and lymphoproliferative response to mycobacterium tuberculosis antigen in pulmonary tuberculosis. J Clin Immunol 2004;24(5):523-532

10 de Souza CM, Braosi AP, Luczyszyn SM, et al. Association between vitamin $\mathrm{D}$ receptor gene polymorphisms and susceptibility to chronic kidney disease and periodontitis. Blood Purif 2007;25(5-6):411-419

11 Germain P, Staels B, Dacquet C, Spedding M, Laudet V. Overview of nomenclature of nuclear receptors. Pharmacol Rev 2006;58(4):685-704

12 Miyamoto K, Kesterson RA, Yamamoto H, et al. Structural organization of the human vitamin $\mathrm{D}$ receptor chromosomal gene and its promoter. Mol Endocrinol 1997;11(8):1165-1179

13 Mashhadiabbas F, Neamatzadeh H, Nasiri R, et al. Association of vitamin D receptor BsmI, TaqI, FokI, and Apal polymorphisms with susceptibility of chronic periodontitis: a systematic review and meta-analysis based on 38 case -control studies. Dent Res J (Isfahan) 2018;15(3):155-165

14 Heidari Z, Moudi B, Mahmoudzadeh-Sagheb $H$. Immunomodulatory factors gene polymorphisms in chronic periodontitis: an overview. BMC Oral Health 2019;19(1):29

15 Inagaki K, Krall EA, Fleet JC, Garcia RI, Vitamin D. Vitamin D receptor alleles, periodontal disease progression, and tooth loss in the VA dental longitudinal study. J Periodontol 2003;74(2):161-167 
16 Ainamo J, Bay I. Problems and proposals for recording gingivitis and plaque. Int Dent J 1975;25(4):229-235

17 O'Leary TJ, Drake RB, Naylor JE. The plaque control record. J Periodontol 1972;43(1):38

18 Ramfjord SP, Emslie RD, Greene JC, Held AJ, Waerhaug J. Epidemiological studies of periodontal diseases. Am J Public Health Nations Health 1968;58(9):1713-1722

19 American Academy of Periodontology. American Academy of Periodontology Task force report on the update to the 1999 classification of periodontal diseases and conditions. J Periodontol 2015;86(7):835-838

20 Pani MA, Knapp M, Donner H, et al. Vitamin D receptor allele combinations influence genetic susceptibility to type 1 diabetes in Germans. Diabetes 2000;49(3):504-507

21 Gunes S, Sumer AP, Keles GC, et al. Analysis of vitamin D receptor gene polymorphisms in patients with chronic periodontitis. Indian J Med Res 2008;127(1):58-64

22 Zhang L, Meng HX, Zhao HS, et al. [Correlation study on polymorphisms of vitamin $D$ receptor gene in patients with periodontitis]. Beijing Da Xue Xue Bao 2010;42(1):37-40

23 Tobón-Arroyave SI, Isaza-Guzmán DM, Pineda-Trujillo N. Association study of vitamin D receptor (VDR) - related genetic polymorphisms and their haplotypes with chronic periodontitis in Colombian population. J Clin Diagn Res 2017;11(2):ZC60-ZC66

24 Nazemisalman B, Vahabi S, Sabouri E, Hosseinpour S, Doaju S. Association of vitamin D binding protein and vitamin D receptor gene polymorphisms in Iranian patients with chronic periodontitis. Odontology 2019;107(1):46-53

25 Ho YP, Lin YC, Yang YH, et al. Association of vitamin D receptor gene polymorphisms and periodontitis in a Taiwanese Han population. J Dent Sci 2017;12(4):360-367

26 Ratheesh V, Subramanian S, Prakash PSG, Victor DJ. Evaluation of association of vitamin $\mathrm{D}$ receptor genetic polymorphism with severe chronic periodontitis in an ethnic Tamilian population. Genet Test Mol Biomarkers 2018;22(10):615-621

27 Marian D, Rusu D, Stratul SI, Calniceanu H, Sculean A, Anghel A. Association of vitamin D receptor gene polymorphisms with chronic periodontitis in a population in western Romania. Oral Health Prev Dent 2019;17(2):157-165
28 Karasneh JA, Ababneh KT, Taha AH, et al. Association of vitamin $\mathrm{D}$ receptor gene polymorphisms with chronic and aggressive periodontitis in Jordanian patients. Eur J Oral Sci 2013;121(6):551-558

29 Zhang JC, Geng HO, Ma WB, Huang P, Pang RY, Zhang YH. [Association of vitamin $\mathrm{D}$ receptor gene polymorphisms with the susceptibility to chronic periodontitis of Han nationality]. Zhonghua Kou Qiang Yi Xue Za Zhi 2005;40(1):50-53

30 Tachi Y, Shimpuku H, Nosaka Y, et al. Vitamin D receptor gene polymorphism is associated with chronic periodontitis. Life Sci 2003;73(26):3313-3321

31 Martelli FS, Mengoni A, Martelli M, Rosati C, Fanti E. VDR Taql polymorphism is associated with chronic periodontitis in Italian population. Arch Oral Biol 2011;56(12):1494-1498

32 Nibali L, Parkar M, D'Aiuto F, et al. Vitamin D receptor polymorphism (-1056 Taq-I) interacts with smoking for the presence and progression of periodontitis. J Clin Periodontol 2008;35(7):561-567

33 Cao XJ, He L, Meng HX, Li P, Chen ZB. [Relationship between vitamin $\mathrm{D}$ receptor gene polymorphisms and chronic periodontitis]. Beijing Da Xue Xue Bao 2015;47(4):697-702

34 Zhang L, Yin X, Wang J, et al. Associations between VDR gene polymorphisms and osteoporosis risk and bone mineral density in postmenopausal women: a systematic review and meta-analysis. Sci Rep 2018;8(1):981

35 Yu F, Cui LL, Li X, et al. The genetic polymorphisms in vitamin $D$ receptor and the risk of type 2 diabetes mellitus: an updated meta-analysis. Asia Pac J Clin Nutr 2016;25(3):614-624

36 Rai V, Abdo J, Agrawal S, Agrawal DK, Vitamin D. Vitamin D receptor polymorphism and cancer: an update. Anticancer Res 2017;37(8):3991-4003

$37 \mathrm{Lu} \mathrm{S}$, Guo S, Hu F, et al. The associations between the polymorphisms of vitamin $\mathrm{D}$ receptor and coronary artery disease: a systematic review and meta-analysis. Medicine (Baltimore) 2016;95(21):e3467

38 Li L, Wan Q Yang S, Zhao S. Impact of vitamin D receptor gene polymorphism on chronic renal failure susceptibility. Ther Apher Dial 2018;22(6):575-587 